\title{
Disciplining the Party
}

Xi Jinping's anti-corruption campaign and its limits

\section{Samson Yuen}

\section{(2) OpenEdition}

\section{Journals}

Electronic version

URL: http://journals.openedition.org/chinaperspectives/6542

DOI: 10.4000/chinaperspectives.6542

ISSN: 1996-4617

\section{Publisher}

Centre d'étude français sur la Chine contemporaine

\section{Printed version}

Date of publication: 1 September 2014

Number of pages: 41-47

ISSN: 2070-3449

\section{Electronic reference}

Samson Yuen, « Disciplining the Party », China Perspectives [Online], 2014/3 | 2014, Online since 01 January 2017, connection on 15 September 2020. URL : http://journals.openedition.org/ chinaperspectives/6542 


\title{
CefC News Analysis
}

\section{Disciplining the Party}

\author{
Xi Jinping's anti-corruption campaign and its limits
}

\section{SAMSON YUEN}

W hen Chinese president Xi jinping vowed to crack down on both senior leaders and low-level bureaucrats - or "tigers" and "flies" as he put it (laohu cangying yiqida 老虎苍蝇一起打) - after he was elected to the post of CCP General Secretary in November 2012, few could have thought that his words could grow into one of the largest campaigns against corruption and petty officialdom in China's modern history. Since then, dozens of powerful leaders, along with many low-level officials, have been put under investigation, indicted, or convicted, including former Chongqing Party secretary Bo Xilai, a score of senior officials, and stateowned enterprise executives connected to former security tsar Zhou Yongkang, PLA Central Military Commission vice-chairman Xu Caihou, and, more recently, the vice-chairman of the Chinese People's Political Consultative Conference (CPPCC), Su Rong. ${ }^{(1)}$ For all its unprecedented scale and intensity, to what extent can the anti-corruption campaign curtail widespread corruption in the long run?

This article takes the view that Xi Jinping's anti-corruption drive resembles a party-building campaign for amassing political power amidst China's fragmented power structure rather than a systemic remedy to cure endemic corruption. Although the anti-corruption drive appears unswerving, given its unceasing effort in probing high-ranking officials and its expansive scope of investigation that has been spilling into formerly unchallenged sectors, the campaign is likely to fall short of its claimed ambition. A closer look at the campaign indicates that it relies heavily on the opaque Party disciplinary mechanism rather than on the legal system to investigate and punish officials. In addition, the campaign catalyses the concentration of power among Party agencies affiliated with $\mathrm{Xi}$ in the name of anti-corruption as opposed to installing genuine checks and balances. Consequently, the campaign might reinforce the authoritarian system that has engendered widespread graft in the first place, and could sow seeds of future corruption.

\section{A dramatic beginning}

$X i$ Jinping's extensive campaign against graft began with one of the most unlikely and dramatic episodes in Chinese politics. In February 2012, Wang Lijun, then head of Chongqing's Public Security Bureau, fled to the US Consulate in Chengdu in an alleged attempt to seek political asylum. After the United States reportedly denied Wang's request, his failed defection cracked open a Pandora's Box that exposed the biggest political scandal in the Chinese Communist Party since the fall of former Shanghai municipal Party secretary Chen Liangyu in 2006. It brought to light the alleged murder of an English businessman by Gu Kailai, wife of then Chongqing Party chief
Bo Xilai, and triggered widespread rumours of a fermenting coup plot against $\mathrm{Xi}$ Jinping involving both $\mathrm{Bo}$ and retired public security tsar Zhou Yongkang. Within a month, Bo, once a likely candidate for promotion to the elite Politburo Standing Committee, was dismissed for "serious disciplinary violations" and was subsequently sentenced to life imprisonment for bribery, embezzlement, and abuse of power.

Bo's political scandal, which followed a year-long probe into former Minister of Railways Liu Zhijun, paved the way for Xi Jinping to make anti-corruption a centrepiece of his agenda right after he came to power. In his first speech as Party General Secretary, Xi highlighted the importance of cracking down on graft and corruption:

In this new environment, our Party is confronted with many severe challenges. There are many pressing problems within the Party that needs [sic] to be resolved urgently, especially the graft and corruption cases that occurred to some of the Party members and cadres, being out of touch from the general public, bureaucracy and undue emphasis on formalities - they must be resolved with great efforts. The whole Party must be vigilant against them. To forge iron, one must be strong. Our responsibility is to work with all comrades in the party, to make sure the Party supervises its own conduct and enforces strict discipline, effectively deals with the prominent issues facing the Party, earnestly improves the working style of the Party and maintains close ties with the people. (2)

Failing to tackle corruption, as Xi emphasised in a subsequent speech, "will inevitably lead to the downfall of the party and the state (wangdang wangguo 亡党亡国)." (3) Strong rhetoric was accompanied by the imposition of concrete rules. On 4 December 2012, Xi announced an "eight-point code" to impose restrictions on official behaviour (baxiang guiding 八项规定) at a Party Central Committee meeting. The rules required government officials to reconnect with the masses, banned the use of luxury cars, eliminated lavish gifts, and reduced pomp, banquets, ceremony, bureaucratic visits, and meetings. A catchy expression - four dishes and a soup (sicai yitang 四菜一 汤) - which has been used by Party leaders since the Mao era to symbolise

1. The list of high-level officials under probe is frequently updated here: http://news.163.com/special/luomagaoguan/ (accessed on 16 July 2014).

2. "Xi Jinping meets press," Sina News, 15 November 2012, available at http://english.sina.com/ video/2012/1114/526824.html (accessed on 11 July 2014).

3. "China's Xi Amassing Most Power Since Deng Raises Reform Risk," Bloomberg News, 31 December 2013. 
Graph 1 - Party disciplinary investigation into Chinese officials

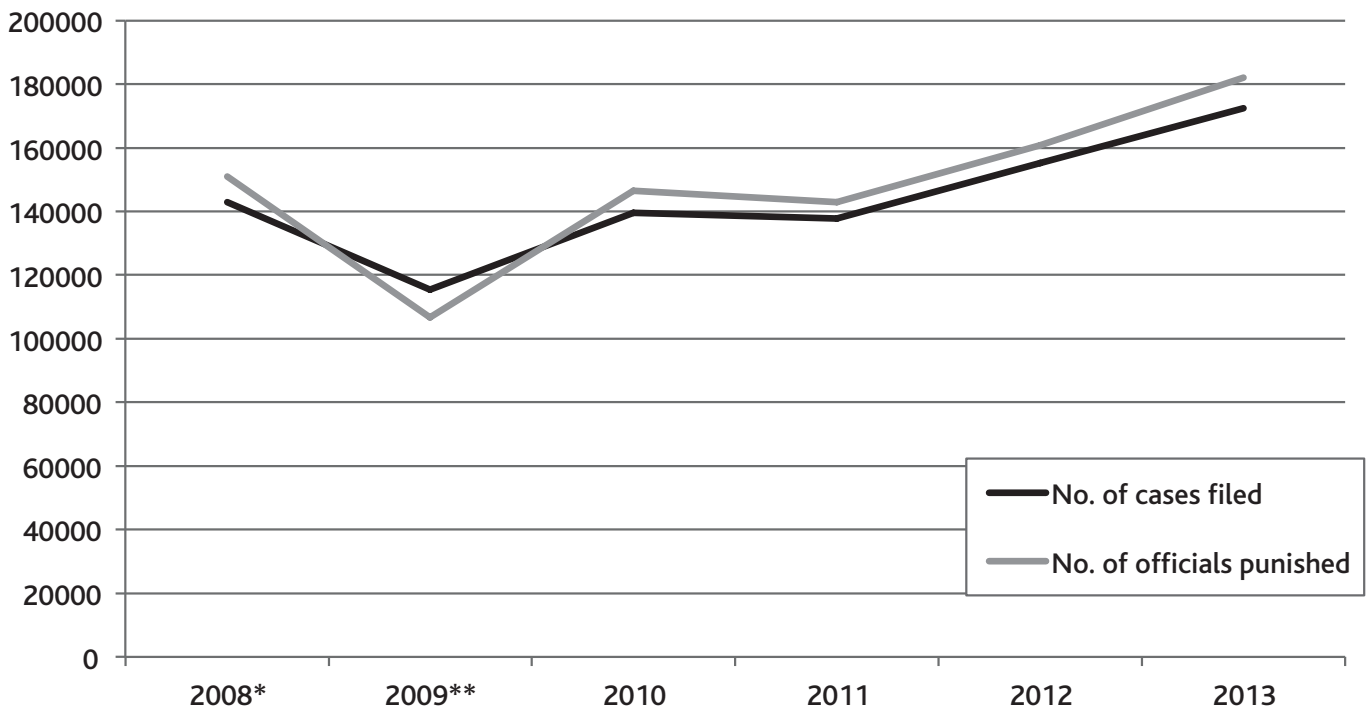

*For the year 2008, numbers are projected based on the released data from November 2007 to November 2008.

** For 2009, numbers are projected based on the data released for January 2009 to November 2009. It is thus expected that the actual number for the full year is higher.

frugality, was cited to sum up the austerity measures. (4) In March 2013, a few days after becoming China's new President, Xi visited Lankao County, Henan Province, where he urged rural officials to make "spicy" efforts to "sweat" corruption out of their systems. (5) "The weapons of criticism and self-criticism," Xi stressed in the poor rural county, "should be well-wielded with some spice to make every party official blush and sweat a little." (6) In June 2013 , addressing a conference that inaugurated a year-long mass-line education campaign, Xi called for the "thorough cleanup" of four undesirable work styles (sifeng 四風) - formalism, bureaucratism, hedonism, and extravagance - in reference to the three ill winds - subjectivism, sectarianism, and stereotyped Party writing - that Mao Zedong cited during the Yan'an Rectification Movement in the 1940s. ${ }^{(7)}$ The process will be painful and requires courage, as Xi noted at the plenary session of the Communist Party's Central Commission for Discipline Inspection (CCDI) in January 2014, like "a man who severs his snake-bitten hand to save his life (刮骨疗毒、壮士 断腕)." (8)

\section{Cracking down on big tigers and small flies}

With immediate effect, Xi's anti-corruption campaign swept across all spectrums of the Party-state bureaucracy. In 2013, more than 180,000 officials were punished for disciplinary issues, compared with around 160,000 in 2012 and 140,000 in 2011 (see Graph 1). ${ }^{(9)}$ In the same year, the Party disciplinary agency reported more than 24,000 cases in violation of the "eight-point code," involving around 30,000 officials, of whom approximately $25 \%$ were given Party or state disciplinary punishment. ${ }^{(10)}$ Although the majority of them were low-level officials, one notable pattern has been a substantial increase in the number of powerful leaders - or "tigers" as Xi put it - accused of graft or power abuse. In the 492 days since the CCDI announced the investigation into Li Chuncheng, a former deputy secretary of the Sichuan Provincial Party Committee, on 6 December 2012, the website of the Commission has reported 285 high-level officials brought under Party investigation. Some of them have been given disciplinary punishment, with a portion of cases passed on to the courts. ${ }^{(11)}$
It must first be noted that anti-corruption is not something new to Party leaders. As Graph 1 and 3 both indicate, the anti-corruption effort accelerated in the late 1990s under jiang Zemin and also from 2009 onward under $\mathrm{Hu}$ Jintao. Although there has been a notable increase in Party disciplinary investigations, one can say that Xi merely continued what Hu had started towards the end of his term. However, one feature definitely distinguishes Xi's campaign - many of the senior officials probed in the course of the anti-corruption campaign have either direct or indirect ties to retired Party leaders. A key figure is the retired public security chief and former Politburo Standing Committee member Zhou Yongkang, who is widely believed to have been placed under detention at the end of last year. Li Chuncheng, one of the earliest officials detained under Xi's campaign, was a protégé of Zhou when the latter was in charge of Sichuan Province in the late 1990s. In subsequent months, a score of Sichuan leaders with links to Zhou were brought under investigation one after the other, including former deputy

4. "China's Luxury Fever and Curbing Official Ostentation," The China Story, date unavailable, available at www.thechinastory.org/key-article/chinas-luxury-fever-and-official-ostentation/ (accessed on 11 July 2014).

5. Zhongyang yaoqiu renzhen xuexi guanche Xi Jinping Lankao diaoyan zhidu jiaoyu shijian huodong zhongyao jianghua jingshen" (Central Government Instructions on the Important Speech on Seriously Studying and Implementing Xi Jinping's Teaching in Lankao County), Xinhua, 24 March 2014, available at http://big5.xinhuanet.com/gate/big5/news.xinhuanet.com/politics/201403/24/c_119917843.htm (accessed on 14 July 2014).

6. "China's Xi urges officials to 'sweat' corruption out of system," Reuters, 18 March 2014

7. "Jizhong jiejue 'sifeng' wenti" (Focus to solve the problem of four undesirable work styles), People's Daily, 25 June 2014

8. "Shi jilü zhenzheng chengwei daidian de gaoyaxian" (Make discipline a high-voltage cable charged with electricity), Xinhua, 14 January 2014, available at http://news.xinhuanet.com/politics/201401/14/c_118967450.htm (accessed on 14 July 2014).

9. The numbers are released by the Central Commission for Discipline Inspection and reported in the media. See "2013 nian chachu shixian weiji weifa zhongguan ganbu 31 ren" (31 central government officials suspected of violation of Party discipline and the law in 2013), Xinhua, 10 January 2014, available at http://news.xinhuanet.com/politics/2014-01/10/c_118914064.htm (accessed on 14 July 2014)

10. "Sanwan yu ren yin weifan baxiang guiding jingshen bei chufen" (More than 30,000 were punished for violating the spirit of the eight-point code), People.cn, 9 January 2014, available at http://politics.people.com.cn/n/2014/0109/c1001-24065013.html (accessed on 14 July 2014).

11. "Jiedu zhongyang jiwei 'zui yiyue'" (Explaining the most aggressive month of the CCDI), Xinhua News, 24 June 2014, available at http://news.xinhuanet.com/2014-06/24/c_1111293938.htm (accessed on 12 July 2014) 
governor Guo Yongxian and the former chairman of the provincial committee of the CPPCC, Li Chongxi. ${ }^{(12)}$ The purge of Zhou's associates soon radiated from the Sichuan clique to other political circles, with the Party announcing a probe into the former vice-minister of public security, $\mathrm{Li}$ Dongsheng, and the former chief regulator of state-owned enterprises, Jiang Jiemin. Foreign media have reported that more than 300 people with ties to Zhou (including relatives and those who worked with Zhou) have been questioned or arrested. (13) The long-anticipated investigation of Zhou was finally announced by state authorities on 29 July 2014, the day when the Politburo set the theme of the upcoming Fourth Plenum to be "governing the country according to law." (14) The announcement broke the unwritten rule that retired members of the Politburo Standing Committee would not be probed. Zhou, who was suspected of "serious disciplinary violations," became the most senior Chinese official to be investigated since the infamous Gang of Four.

Another feature that distinguishes the current anti-corruption drive from previous ones is its ever-expanding scope of investigation. The campaign so far has not only implicated different ranks of officials spanning provincial and central Party-state bureaucracy, but has also spilled over into numerous economic sectors, many of which have been heavily dominated by state-owned enterprises, as well as Party-state units that have remained intact from previous corruption probes. The alleged probe into Zhou Yongkang, for instance, has brought the campaign into the highly lucrative oil industry. Jiang Jiemin, who was arrested after he became the chief regulator of state-owned enterprises, rose through the ranks of the oil industry to head China's biggest oil giant, the China National Petroleum Corporation (CNPC), of which Zhou was also a former head. Since jiang's detention, dozens of top executives at the CNPC and its subsidiary PetroChina have been placed under investigation. ${ }^{(15)}$ The crackdown on the state economy has recently spread to other big state-run conglomerates. Song Lin, the former chairman of China Resources, a Hong Kongbased trading company and one of China's largest state-owned enterprises, was accused of power abuse in corporate dealings, and was arrested in April 2014. Other probe targets, to name just a few, include other parts of the highly monopolistic energy sector, such as power companies, the state broadcaster CCTV, where bribery in exchange for national airtime is an open secret, and the poorly regulated healthcare sector, where foreign companies have been active.

Perhaps the most ambitious move so far has been the ingress into the powerful and largely secluded People's Liberation Army (PLA). The PLA has been a notorious breeding ground of corruption, but has never become a serious target in previous crackdowns. ${ }^{(16)}$ In January 2013, policemen surrounded a massive mansion in Puyang, Henan Province, owned by Gu Junshan, the former deputy head of the PLA General Logistics Department, who managed the military's resources, prized assets, and extensive land holdings. Gu's lavish lifestyle was exposed in an investigative piece published by the Chinese magazine Caixin, which reported how investigators uncovered crates of expensive Maotai liquor and a number of gold items, including a wash basin and Mao Zedong statute, in his palace-like mansion. ${ }^{(17)} \mathrm{Gu}$ himself had been removed from office in early 2012, before Xi came to power, amidst rumours that General Liu Yuan, son of Liu Shaoqi and a close ally of $X i$ Jinping had vowed to crack down on corruption in the PLA. ${ }^{(18)}$ As the most senior officer to be tried in a military court since 2006, Gu was charged in April 2014 with corruption, bribery, embezzlement, and power abuse. The corruption crackdown that started with $\mathrm{Gu}$ has since moved further up the ranks. General Xu Caihou, a former vicechairman of the Central Military Commission who was described as a trusted ally of both Jiang Zemin and Hu Jintao, was removed from office and became the highest-ranking official to have fallen victim to the anticorruption campaign thus far. The expulsion of both $\mathrm{Gu}$ and Xu has signalled Xi's determination to shake up the military. By singling out high-profile "tigers" among corrupt army officials, these unusual moves intend to demonstrate that even the powerful military is not immune from the campaign, while also allowing Xi to tighten his grip on the army by instating generals loyal to him. ${ }^{(19)}$

Nonetheless, the unprecedented scope, depth, and intensity of the campaign as well as the selectiveness of its targets have raised speculation that the effort is a camouflage for power struggle - a tool for President $X i$ to remove his political opponents. The politically ambitious Bo Xilai, for example, was a known rival of Xi Jinping who purportedly competed with him for the top leadership position. As observers have further pointed out, most of the officials removed from office have connections to powerful Party leaders. Targeting Zhou and his allies, for example, is said to be ultimately aiming for Zeng Qinghong, also a retired Party leader and close ally of Jiang Zemin, who allegedly played a key role in bringing Zhou to the top ranks. (20) Apart from associates of Zhou Yongkang and Zeng Qinghong, others targeted were officials and executives connected with other retired Party leaders such as Li Peng and He Guoqiang, as indicated by probes into the energy sector and into the chief of China Resources, respectively. ${ }^{(21)}$ Another observer has noted a purge against Hu Jintao's Communist Youth League (CYL) faction, based on the probe into Ling Zhengce, vice chairman of the Shanxi provincial committee of the CPPCC and brother of Ling Jihua, a former aide to $\mathrm{Hu}$. ${ }^{(22)}$ Regardless of whether these are Xi's personal purges, the anti-corruption campaign is certainly aimed at clearing the way for deepening reforms (shenhua gaige 深化改 革) and enhancing public faith in Xi Jinping's leadership. It has long been held that Party factionalism and vested interests, especially in the stateowned sectors, have made the economic reforms proposed in the Third Plenum of the $18^{\text {th }}$ Party Congress difficult to implement. As The Diplomat's Shannon Tiezzi explained:

12. "Sichuan political adviser Li Chongxi investigated," South China Morning Post, 30 December 2013.

13. Benjamin Kang Lim and Ben Blanchard, "China seizes $\$ 14.5$ billion assets from family, associates of ex-security chief: sources," Reuters, 30 March 2014.

14. "CPC captures 'big tiger' in anti-graft campaign," Xinhua, 29 July 2014.

15. Jeremy Page, Wayne Ma, Brian Spegele, "China Probes Former Oil Company Head," The Wall Street Journal, 1 September 2013.

16. Jonathan Ansfield, "Leader of China Aims at Military with Graft Case," The New York Times, 31 March 2014, www.nytimes.com/2014/04/01/world/asia/chinese-military-general-charged-ingraft-inquiry.html?_r=1 (accessed 21 July 2014).

17. Wang Heyan, "How a PLA General Built a Web of Corruption to Amass a Fortune," Caixin, 16 January 2014, available at http://english.caixin.com/2014-01-16/100630028.html (accessed on 14 July 2014).

18. Kathrin Hille, "Chinese general faces corruption probe," Financial Times, 1 February 2012, www.ft.com/intl/cms/s/0/f727d84a-4cd9-11e1-8741-00144feabdc0.html\#axzz36lb1/4sn (accessed on 21 July 2014).

19. Minnie Chan, "Xi Jinping promotes 10 more to PLA general, including two in Hong Kong," South China Morning Post, 4 August 2013; Keira Lu Huang, "PLA's number 3 official, once promoted by Xu Caihou, pledges loyalty to Xi Jinping," South China Morning Post, 4 July 2014.

20. Raymond Li, "Zhou Yongkang's rise to power fuelled by oil," South China Morning Post, 31 August 2013.

21. Jamil Anderlini, "China Resources chairman in probe as anti-corruption net widens," Financial Times, 18 April 2014.

22. Willy Lam, "With Zhou's Circle Down, Xi's Purge May Turn to Hu," Jamestown Brief, Vol. 14, No. 13, 3 July 2014. 


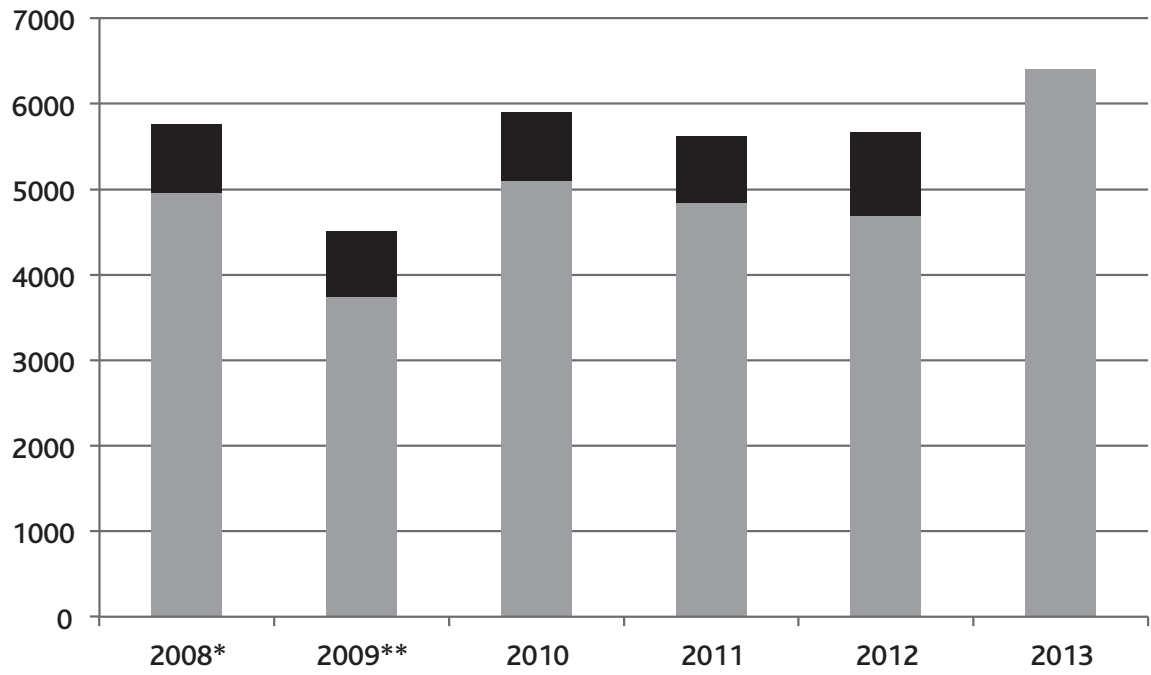

*For the year 2008, numbers are projected based on the released data from November 2007 to November 2008.

** For 2009, numbers are projected based on the data released for January 2009 to November 2009. It is thus expected that the actual number for the full year is higher

*** The data released by the CCDI contains no information about the number of officials transferred to the judicial process in 2013.

The anti-corruption drive makes reform easier in a variety of ways. It lets Xi promote pro-reformist allies to replace purged officials, but also cows others into backing (or at least not opposing) more ambitious reforms. ${ }^{(23)}$

A Reuters report to which Shannon Tiezzi referred suggests that $X i$ is hoping that "removing corrupt officials and those resisting change will allow him to consolidate his grip on power and implement difficult economic, judicial and military reforms that he believes are vital to perpetuate oneparty rule." (24) It quoted well-connected sources that revealed Xi's plan to promote some 200 reform-minded officials from Zhejiang Province, where he served as Party secretary from 2002 to 2007 , to senior Party positions in the coming years. Indeed, some observers have argued that the anticorruption campaign will allow Xi to accumulate political capital and prepare for the next leadeship reshuffle in the 2017 Party plenum. ${ }^{(25)}$ The far-reaching campaign is not without internal resistance, however. According to the Financial Times, retired leaders Jiang Zemin and Hu Jintao have reportedly urged $\mathrm{Xi}$ to rein in the anti-corruption campaign, warning him not to "take on too many of the powerful families or patronage networks at the top of the party hierarchy." (26)

\section{Heavy reliance on the Party disciplinary mechanism}

Whether the anti-corruption drive will make way for more aggressive economic reforms is yet unknown, but it has certainly taken both social and economic tolls. From January 2013 to April 2014, 54 Party-state officials died of unnatural causes, with 23 reportedly committing suicide. Although surveys have indicated that the pressure officials faced when wrestling with the unspoken rules of the bureaucratic system (guanchang qianguize 官场 潜规则) was the primary cause behind most suicides, the anti-graft campaign is seen as a triggering factor. (27) A People's Daily editorial published in July 2014 specifically warned that "the current rectification movement must avoid killing people" (zhengfeng buneng zhengsi ren 整风不能整死 人). ${ }^{(28)}$ On the economic side, the anti-graft investigations together with the austerity measures have resulted in spending contraction in all sectors of the economy, including restaurants, luxury products, automobiles, and the real estate market. ${ }^{(29)}$ A report issued by Bank of America Merrill Lynch estimated that the anti-corruption campaign could cost the economy more than US\$100 billion in 2014. ${ }^{\left({ }^{30}\right)}$ It is difficult to know whether the austerity measures will have long-term effect, or whether power can genuinely be exercised within the cage of regulations (ba quanli guanjin zhidu de longzi li 把权力关进制度的笼子里), as Xi once said at the CCDI. (31) Commission chief Wang Qishan has candidly acknowledged that the "shock and awe" (zhenshe 震慑) tactics of the campaign are mainly intended to treat the symptoms so as to buy time to cure the disease (以治标为主, 为治本赢得 时间). (32)

23. Shannon Tiezzi, "What's behind Xi's anti-corruption campaign," The Diplomat, 17 April 2014, available at http://thediplomat.com/2014/04/whats-behind-xis-anti-corruption-campaign (accessed on 14 July 2014).

24. Benjamin Kang Lim and Megha Rajagopalan, "China's Xi purging corrupt officials to put own men in place: sources," Reuters, 16 April 2014.

25. Ting Shi, "Xi's Anti-Corruption Campaign Signals Power Play for 2017," Bloomberg, 5 July 2014.

26. Jamil Anderlini and Simon Rabinovitch, "Ex-president Jiang urges Beijing to curb anti-corruption drive," Financial Times, 31 March 2014.

27. "Meiti jiexi shinian baiyu guanyuan zisha: fanfu bingfei zhuyin" (Media analyse the cause behind the suicide of more than a hundred officials over the past ten years - anti-corruption isn't the main cause), Nanfang Zhoumo (Southern Weekend), 17 April 2014.

28. "Shenzhong chuzhi fan cuowu dangyuan ganbu Zhengfeng buneng zhengren" (Carefully handle Party members and cadres who made mistakes; rectification must avoid killing people), People's Daily, 12 July 2014.

29. Andrew Jacobs, "Elite in China Face Austerity under Xi's Rule," The New York Times, 27 March 2013.

30. Jack Perkowski, "The Price of Fighting Corruption in China," Forbes, available at www.forbes.com/sites/jackperkowski/2014/06/05/the-price-of-fighting-corruption-in-china/ (accessed on 14 July 2014).

31. "Ba quanli guanjin zhidu de longzi li" (To lock power into the cage of regulations), China News, 22 January 2013, available at www.chinanews.com/gn/2013/01-22/4510583.shtml (accessed on 14 July 2014).

32. "Wang Qishan: dangqian fanfu yaoyi zhibiao weizhu, wei zhiben yingde shijian," (Wang Qishan: Current anti-corruption effort should focus on curing the symptoms to win time for curing the disease), Caixin, 25 January 2013, available at http://china.caixin.com/2013-0125/100486367.html (accessed on 14 July 2014). 


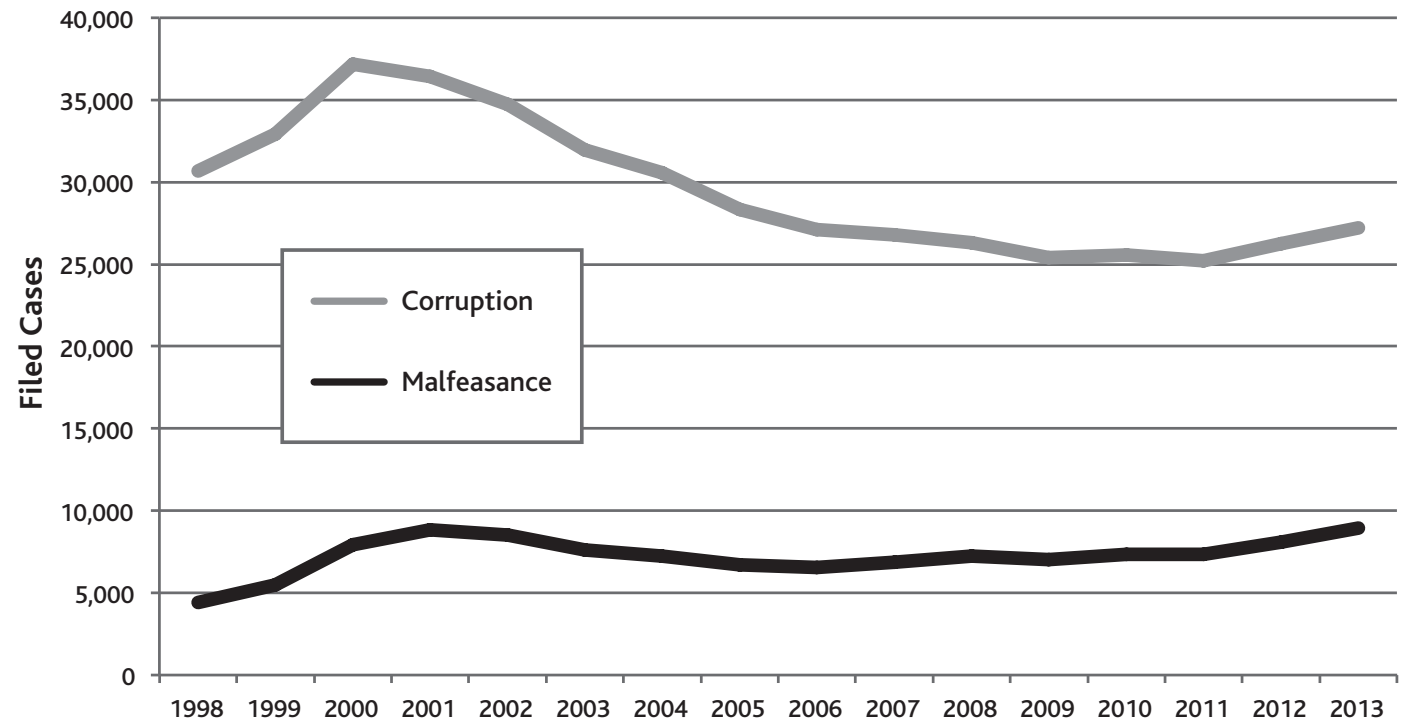

What is clear, however, is that the anti-corruption drive has displayed characteristics of a Party-building campaign. One distinguishing feature is the heavy reliance on the Party disciplinary mechanism rather than the legal system. The austerity measures, for instance, were introduced by the Party Central Committee (not by the supreme lawmaking body, the National People's Congress) as an additional set of Party disciplinary codes that make Party-state officials and civil servants liable to punishment under the existing Chinese Communist Party discipline regulations (Zhongguo gongchandang jilü chufen tiaoli 中国共产党纪律处分条例). ${ }^{(33)}$ To strengthen Party discipline, local Party committees are launching self-criticism sessions among officials as part of a mass line education campaign (qunzhong luxian jiaoyu shijian yundong 群众路线教育实践运动). These Party-led, so-called "democratic life meetings" (minzhu shenghuo hui 民主生活会), which were first introduced in Yan'an in the early 1940s as a tool to strengthen Party democracy by allowing people to voice their opinions about one another, are now being revived across China for local officials to confess their mistakes and criticise one another so as to expose traces of the "four undesirable work styles." (34)

The role of Party discipline is particularly salient in the investigation of corrupt officials. Investigations are typically initiated by the Central Commission for Discipline Inspection, and are subsequently reported on its website. The majority of officials placed under investigation are described as "having violated both Party discipline and the law" (weiji weifa 违纪违法). ${ }^{(35)}$ But apart from this and a few sentences about the position of the officials being probed, there is often no other information released about which Party disciplinary code or law the officials have breached. Officials under probe are mostly detained using the shuanggui (双规) or "double designations" process, which is an extralegal, inner-Party detention process requiring Party members to be questioned for a designated duration at a designated place. Although many see shuanggui as a powerful tool for capturing corrupt officials, others, including scholars, activists, and journalists, have criticised the system for its brutality and total absence of transparency. ${ }^{(36)}$ Once the investigation is completed, Party members can be stripped of their Party membership (kaichu dangji) and handed over to the judiciary organs, which then ostensibly begin a legal investigation leading to a trial.
For officials convicted of their offences, the investigation process is often followed by disciplinary punishment within the Party. Among the 180,000 officials punished for disciplinary violations, around 150,000 have been subjected to Party disciplinary punishment, with the rest being punished by state discipline (zhengji 政纪) or both. ${ }^{(37)}$ According to official statistics (see Graph 2), only a small portion of high-level officials were transferred to the formal prosecution system, and apart from high-profile arrests (i.e. top officials) who are almost certain to be handed over to the courts after the investigative period, others are more often given Party disciplinary punishment rather than being transferred to the judicial process. More importantly, it is often unclear what such punishment entails, and also what determines if a certain case will be handed over to the courts. The reliance on the opaque Party disciplinary mechanism instead of the relatively more transparent legal system to punish corrupt officials is further indicated by official statistics on filed court cases. As Graph 3 shows, although there has been a pick-up in the number of filed cases by the People's Procuratorate on both corruption and malfeasance in 2013 , the number of corruption cases in particular is still way below the peak in 2000 .

33. "Zhongguo gongchandang jilü chufen tiaolu" (Regulation of the Communist Party of China on Disciplinary Actions), available at www.people.com.cn/GB/shizheng/1026/2346251.html (accessed on 14 July 2014); "Zhongjiwei zheng zhiding weifan baxiang guiding shiyong jilü chufen tiaoli jieshi" (CCDI is drafting explanation of how violation of the eight-point code can result in disciplinary punishment), China News, 31 May 2013, available at http://news.ifeng.com/mainland/detail_2013_05/31/25942859_0.shtml (accessed on 14 July 2014).

34. Zhang Hong, "Sweating and on the verge of tears: Chinese officials carry out self-criticism on TV," South China Morning Post, 28 September 2013.

35. In a round-up of 67 cases released between May and June 2014, Xinhua reporters found that 47 cases violated both Party discipline and the law, 17 cases violated Party discipline only, and three cases violated the law only. See "liedu zhongyang jiwei 'zui yiyue"' (Explaining the most aggressive month of the CCDI), Xinhua News, 24 June 2014, available at http://news.xinhuanet.com/201406/24/C_1111293938.htm (accessed on 12 July 2014), or Larry Catá Backer's blogpost: http://lcbackerblog.blogspot.hk/2011/08/communist-party-and-state-discipline-in.html.

36. Gillian Wong, "In China, Brutality Yields Confessions of Graft," Associated Press, 10 March 2014; for more about the shuanggui system, see Flora Sapio, "Shuanggui and extralegal detention in China," China Information, Vol. 22, No.1, 2008, pp. 7-37. Also see the documentary filmed by the recently arrested lawyer activist Pu Zhiqiang on the shuanggui case in Yongzhou, where Party officials were brutally tortured during the shuanggui process: www.youtube.com/ watch?v=XswaTKp-NCw (accessed on 28 August 2014).

37. State disciplinary actions are punishment given to civil servants. See http://baike.baidu.com/ view/4001897.htm (accessed on 28 August 2014). 


\section{Centralising power as opposed to installing institutional checks and balances}

The dependence on Party discipline throughout the anti-corruption drive has also fostered the centralisation of power in the CCDI, the Party's top disciplinary body. Although the Chinese government has established various agencies to deal with endemic corruption, such as the National Bureau of Corruption Prevention (guojia yufang fubai ju 国家预防腐败局) under the State Council and the Anti-Corruption Bureau ( fan tanwu huilu ju 反贪污贿 赂局) under both central and local People's Procuratorates, the main responsibility for investigating suspected cases of corruption and malfeasance within the Party ranks still falls on the CCDI and its provincial arms. However, unlike anti-corruption bodies such as Hong Kong's Independent Commission Against Corruption (ICAC) and Singapore's Corrupt Practices Investigation Bureau (CPIB), which are independent of the government administration, the CCDI is an internal Party agency designed to install checks and balances from within the Communist Party, relying on the removal of corrupt officials as a necessary means to restore Party discipline and maintain one-party rule.

The success of the self-disciplinary system has been rather limited, however. One of the critical problems lies in the dual supervision system of the provincial commissions for discipline inspection. According to this system, which has been in place since 1980, local discipline inspection bureaus are placed under the dual leadership of the upper-level Disciplinary Inspection Commission and the same-level local Party Committee. In practice, however, the vertical line of supervision is often dwarfed by the territorial jurisdiction of the local Party committees. The latter maintain substantial influence over the local disciplinary commissions by paying their budgetary expenses as well as the wages and welfare benefits of discipline inspectors. In addition, the career prospects of local discipline inspectors are greatly dependent upon local Party committees. In order to stand better chances for promotion, local discipline inspectors often need to cultivate good relationships with local Party committee members in order to secure their support in evaluation. This dynamic forms a strong disincentive for the local disciplinary body to initiate investigations into local government officials. In addition, as observers have pointed out, local discipline inspection bureaus can even become a platform for power struggles between various local factions, and the local disciplinary body and the local government could collude in rent-seeking, exacerbating the corruption problems that disciplinary inspectors are tasked to tackle. ${ }^{(38)}$ All this has weakened the power of the internal Party disciplinary mechanism.

To reduce the influence of territorial Party committees on local disciplinary bodies, one major part of Xi's anti-corruption campaign has been to expand the power of the CCDI and strengthen vertical control over its local units. To this end, the Third Plenum resolution announced in November 2013 introduced several measures to strengthen the supervision of local disciplinary bodies over same-level Party committees. The local discipline inspection commission is now required to report ongoing investigations not only to the local Party committee but also to the supervising disciplinary body. More significantly, the resolution adopted the system of vertical nomination (chuizhi timing 垂直提名), in which the upper-level disciplinary body regains the power of appointment of lower-level discipline inspectors, making them less dependent on local government officials. ${ }^{(39)}$ While some observers see the nomenklatura reform as a breakthrough, others are less positive because the reform has not provided further details on the criteria for initiating an investigation, and also because it has not addressed other possible means of local political interference, such as the budgetary control local Party committees wield over local disciplinary bodies. ${ }^{(40)}$

Appearing not to intend to abolish the dual supervision system of the local disciplinary bodies, the CCDI has instead chosen to expand its power at the centre. CCDI chief Wang Qishan has vowed to maintain full coverage of inspection at all levels of local governments, Party units, state ministries, universities, and state-owned enterprises, using inspection tours (xuncha 巡 查) and stationing (jinzhu 进驻) as two main pivots to detect and report corrupt practices. In addition, special inspection teams (zhuanxiang xunchazu 专项巡查组) will be dispatched to selected Party-state units to conduct spot checks in addition to routine inspections. Efforts to expand the power of the CCDI were further stepped up in 2014. The CCDI established three new internal offices, including two discipline inspection divisions that focus on local governments, bringing the total number of such divisions to 12, along with a division tasked with the internal supervision of discipline inspection officers. Inspection tours to local governments and party-state agencies will increase from two to three rounds, and three more special inspection teams will be formed. Provincial discipline inspection commissions have also been expanded through a personnel increase of approximately $60 \% .(41)$

The rapid empowerment of the CCDI raises a further question. While the expansion of the top disciplinary body aims to strengthen internal Party monitoring of its cadres and officials, it raises the concern that no other agencies can effectively constrain its authority. Even though the CCDI has recently set up an internal supervisory unit to monitor itself and has even initiated graft investigations against its own inspectors, ${ }^{(42)}$ these moves still do not address the question of who else can monitor the CCDI. In fact, in order for the anti-corruption campaign to achieve the effect of "shock and awe," the CCDI is likely to further expand its powers and demonstrate that it has no limits in taking down powerful "tigers" and lowly "flies." The expansion of central power has already led some to warn of Xi Jinping's autocratic turn. ${ }^{(43)}$ Indeed, over the past two years, Xi has not only relentlessly targeted "tigers" and "flies" alike, but has also begun a massive crackdown on civil society and the Internet. Advocates calling for the disclosure of Party officials' assets, together with journalists, lawyers, civil society activists, and social media celebrities, have all been subject to greater control and repression. Xi himself is believed to have secured firm power, as he has become not only the head of the Party-state and the military, but now also chairs the newly-established National Security Commission and Leading small

38. Zhang Lin, "Zhongjiwei guoquan de lixiang yu xianshi" (Behind the expansion of power of CCDI: Ideal and reality), Financial Times Chinese, 25 April 2014, available at www.ftchinese.com/story/001055900 (accessed on 14 July 2014).

39. "Zhongjiwei timing shengji jiwei shuji, guan ganbu quanxian kuoda" (CCDI now nominates provincial secretary of the discipline inspection commission, increasing its power of supervision), Jinghua News, 29 March 2014, available at http://epaper.jinghua.cn/html/2014-03/29/content_ 75613.htm (accessed on 14 July 2014).

40. "Jiwei kuoquan: pojie jiandu tongji dangwei nanti" (CCDI's expansion of power: Solving the problem of monitoring same-level Party committee members), Beijing News, 20 November 2013, available at http://epaper.bjnews.com.cn/html/2013-11/20/content_479034.htm?div=-1 (accessed on 14 July 2014).

41. "Difang jiwei kuoquan sanbuqu" (The three steps for provincial committee for discipline inspection to expand power), Jingii Guancha Wang (Economic Observer), 29 June 2014, available at www.eeo.com.cn/2014/0629/262703.shtml (accessed on 14 July 2014).

42. Chris Luo, "Communist Party anti-corruption watchdog investigates one of its own officials," South China Morning Post, 13 April 2014.

43. Jamil Anderlini, "Xi Jinping's anti-corruption drive in China takes autocratic turn," Financial Times, 23 June 2014. 
group on economic reform. Confidence in the system of centralised authority will likely further crowd out spaces for institutional checks and balances as well as the prospects for rule of law.

\section{Conclusion}

Given its unprecedented scope and intensity, Xi Jinping's anti-corruption campaign is expected to rein in corrupt practices by discouraging extravagant official spending and conspicuous power abuse. On the other hand, by implicating scores of high-ranking officials and expanding into a wide range of sectors, the campaign has sent out a clear signal that $\mathrm{Xi}$ and his allies have now consolidated political power against rival factions, and that any political opposition to Xi personally or economic reforms generally can be ruthlessly removed. It must be remembered, however, that the anti-corruption drive, despite its promising rhetoric, is about rescuing the Party and restoring public faith more than eradicating corruption. After all, corruption has been intertwined in complex ways with China's economic development. ${ }^{(44)}$ And as observers argue, the anti-corruption drive is intended only as a means of smoothing the way for economic reforms. ${ }^{(45)}$ In light of this, the anti-corruption campaign will only be conducted to the extent that it clears the way for reforms - without taking down too many high-ranking officials to a degree that threatens the lifeline of the Communist Party. That explains why the anti-corruption campaign has relied heavily on the centralisation of power within the Party disciplinary mechanism rather than on using the legal system or installing institutional checks and balances, as the disciplinary strategy allows the scope of the campaign to be carefully scripted and controlled. In the longer term, however, this continuous expansion of government power in the absence of institutional checks and balances and the rule of law contains the risk of backfiring, as it might engender a whole new set of corruption problems that may be much more difficult to solve.

ISamson Yuen is a PhD student in politics at the University of Oxford and is a research assistant at the CEFC

(samson.yuen@sant.ox.ac.uk).

CEFC News Analysis is compiled from the CEFC's fortnightly selection of Press Highlights, available at www.cef.com.hk. 